DEPÓSITO LEGAL ZU2020000153

Esta publicación científica en formato digital

es continuidad de la revista impresa

ISSN 0041-8811

E-ISSN 2665-0428

Revista

de la

Universidad

del Tunlia

Fundada en 1947

por el Dr. Jesús Emrique Lossada

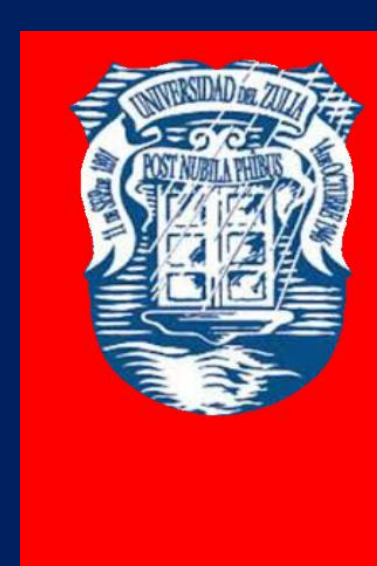

Ciencias

Sociales

y Arte

Aกัต 11 No 31

Septiembre - Diciembre 2021

Tercera ípoca

Maracailbo-Venezuela 
REVISTA DE LA UNIVERSIDAD DEL ZULIA. 3época. Año 11 N³ 31, 2020

Sezer Kanbul et al. /// Examination on implications of Web 2.0 Tools ...559-570

DOI: http://dx.doi.org/10.46925//rdluz.31.37

\title{
Examination on implications of Web 2.0 Tools in the field of Special Education
}

\author{
Sezer Kanbul* \\ Emrah Soykan ** \\ Erinc Erçă $* * *$
}

ABSTRACT

The objective of this article is to analyze the published studies that bear the title Web 2.0 in the field of special education. For this, the electronic databases IEEE Xplore, ScienceDirect, SpringerLink, Taylor \& Francies Online, Wiley and the search engine Google Scholar were scanned in order to locate articles titled Web 2.0. Nineteen articles were selected from the 1220 articles found in the field of special education, and they were analyzed using the content analysis technique. Data were collected using the "Article Publication Form" developed by the researchers. The data obtained in the study were interpreted based on percentage and frequency. The results obtained are believed to lead to further studies.

KEYWORDS: Web 2.0; Special Education; Content Analysis

* Near East University, Distance Learning Center, North Cyprus, Mersin 10 Turkey. ORCID: https://orcid.org/0000-0001-9654-5272. E-mail: sezer.kanbul@neu.edu.tr;

**Near East University, Department of Computer Education and Instructional Technology, North Cyprus, Mersin 10 Turkey. ORCID: https://orcid.org/0000-0002-3635-8739. Email: emrah.soykan@neu.edu.tr

***University of Kyrenia, Department of Computer Education and Instructional Technology, North Cyprus, Mersin 10 Turkey. ORCID: https:/orcid.org/0000-0002-66817625. Email: erinc.ercag@kyrenia.edu.tr

Recibido: 06/07/2020

Aceptado: 02/09/2020 
REVISTA DE LA UNIVERSIDAD DEL ZULIA. 3época. Año 11 N³ 31, 2020

Sezer Kanbul et al. /// Examination on implications of Web 2.0 Tools ...559-570

DOI: http://dx.doi.org/10.46925//rdluz.31.37

\section{Examen sobre las implicaciones de las herramientas Web 2.0 en el campo de la educación especial}

RESUMEN

El objetivo de este artículo es analizar los estudios publicados que llevan el título Web 2.0 en el campo de la educación especial. Para ello, se escanearon las bases de datos electrónicas IEEE Xplore, ScienceDirect, SpringerLink, Taylor \& Francies Online, Wiley y el motor de búsqueda Google Scholar a fin de ubicar artículos titulados Web 2.0. Diecinueve artículos fueron seleccionados de los 1220 artículos que se encontraron en el campo de la educación especial, y fueron analizados mediante la técnica de análisis de contenido. Los datos se recopilaron con el "Formulario de publicación de artículos" desarrollado por los investigadores. Los datos obtenidos en el estudio se interpretaron en base a porcentaje y frecuencia. Se cree que los resultados obtenidos darán lugar a más estudios.

PALABRAS CLAVE: Web 2.0; Educación especial; Análisis de contenido.

\section{Introduction}

Initially defined by O'Reilly, the Web 2.0 concept is the second generation web platform where the user is active with features such as providing information, generating information, sharing and discussing information from users. The concept and tools of Web 2.0 contain a wide range of literature (O'Reilly, 2007).

In order for Web 2.0 tools to be used in the learning processes of students with special needs, both the students and the educators educating them should have knowledge and awareness about this issue.

Peterson-Ahmad \& Somerville, 2018 Eighty-two pre-service teachers participated in the practical study conducted by prospective teachers to use Web 2.0 tools to support the educational needs of disabled students. Participants showed that they were not aware of the answers on the pre-assessment scale, Web 2.0 in general and the purpose of the classroom. At the end of the study, it was seen that students with disabilities had information about Web 2.0 tools and how to use these tools.

The continual emergence of new resources and interaction opportunities from Web 2.0 implies a constant imperative to monitor how these new elements can affect the 
REVISTA DE LA UNIVERSIDAD DEL ZULIA. 3época. Año 11 N³ 31, 2020

Sezer Kanbul et al. /// Examination on implications of Web 2.0 Tools ...559-570

DOI: http://dx.doi.org/10.46925//rdluz.31.37

interaction of people with disabilities and how the current research has managed to address existing problems (Pereira \& Archambault, 2018).

Billingsley et al (2011) emphasize that Web 2.0 technologies can provide the necessary support to education teachers and school leaders who are given responsibility for the education of students with disabilities, and that these teachers can assume more responsibility for educating students with disabilities.

In this context, it is important that the advantages of web 2.0 technologies are recognized by special education teachers, that they are able to use them and that they are aware of the studies conducted in the field.

- Objective of the Study

The aim of the study is to analyze Web 2.0 studies in the field of special education. For this purpose, answer is sought to the following questions:

(1)What is the distribution of articles by the index they are scanned?

(2) What is the distribution of articles by type?

(3) How is the distribution of articles according to the years published?

(4)What is the distribution of articles according to the discipline / subject areas?

(5) What is the distribution of authors by country?

(6) What is the distribution of authors by universities?

(7) What is the distribution of authors according to their academic departments?

(8) What is the distribution of articles according to research methods?

(9) What is the distribution of articles according to the sampling method?

\section{Method}

The research was carried out using qualitative method. As Yildirim and Simsek (1999) stated, qualitative research enables to see the phenomenon from the perspectives of the individuals concerned and to reveal the social structure and processes constituting these perspectives.

\section{1.l. Research Model}

The research is a descriptive study where a general survey model is used. The general survey model is a survey study carried out on the whole universe or on a group to be taken 
REVISTA DE LA UNIVERSIDAD DEL ZULIA. 3época. Año 11 N³ 31, 2020

Sezer Kanbul et al. /// Examination on implications of Web 2.0 Tools ...559-570

DOI: http://dx.doi.org/10.46925//rdluz.31.37

from it in order to reach a general judgment about the universe in a universe consisting of many elements (Karasar, 2002).

The study was structured in accordance with descriptive content analysis, which included the examination of the identified articles, and the descriptive and definitive evaluation of the study orientations and results (Calik \& Sozbilir, 2014). Content analysis, which is widely used in qualitative research, is a method of analysis that quantitatively identifies some features of written texts and serves as a bridge between qualitative analysis and statistical results of materials (Bauer, 2003).

\subsection{Limitations and Scope of the Study}

- $\quad$ The research was limited to IEEE Xplore, ScienceDirect, SpringerLink, Taylor $\& \&$ Francies Online, Wiley electronic databases and Google Scholar search engine.

- The research included 1220 articles of type "Web 2.0" in the mentioned databases.

- 19 articles among 1220 articles related to special education were included in the study.

- $\quad$ The studies of which full text could be reached are included in the study.

- $\quad$ The research was limited to articles published between 2007-2019.

\subsection{Data Collection and Analysis}

In order to collect data for the research questions, an unique Article Publication Form was developed by the researchers. In order to ensure the content validity of the form, a large number of forms used in content analysis studies were examined, a draft form was created, and then the regulations were made by two educational technologies and two special education experts, and the form was finalized after necessary controls. In the form, online electronic resource, year, article type, country, department, university, main theme, research method and sample group themes were included.

'Web 2.0' was written and searched in electronic databases and Google Scholar search engine. As a result, IEEE Xplore (456), ScienceDirect (183), SpringerLink (140), Taylor \& Francies Online (308), Wiley (103) electronic databases and Google Scholar (30) have been reached. Afterwards, 19 articles with special education were identified and selected for 
REVISTA DE LA UNIVERSIDAD DEL ZULIA. 3época. Año $11 \mathrm{~N}^{\circ}$ 31, 2020

Sezer Kanbul et al. /// Examination on implications of Web 2.0 Tools ...559-570

DOI: http://dx.doi.org/10.46925//rdluz.31.37

analysis. The analysis of the data collected using the Article Publication Form was based on research questions. The data obtained from the articles analyzed were transferred to MS Excel program file and analyzed.

\subsection{Validity and reliability}

In order to ensure coding reliability within the scope of the research, articles were coded separately by two researchers and then these encodings were compared. The reliability of this coding was calculated using the formula [Agreement / (Agreement + Disagreement) $\mathrm{x}$ 100] (Miles \& Huberman, 1994). In this context, the mean reliability coefficient between coders was calculated as 93\%. The compliance percentage used to calculate inter-coded reliability is expected to be higher than $70 \%$. In this respect, it can be said that the coding reliability calculated within the scope of this research is acceptable.

\section{Results}

The findings of the research were interpreted by visualizing with percentage and frequency graphs. The findings of the analysis are presented below in parallel with the research questions.

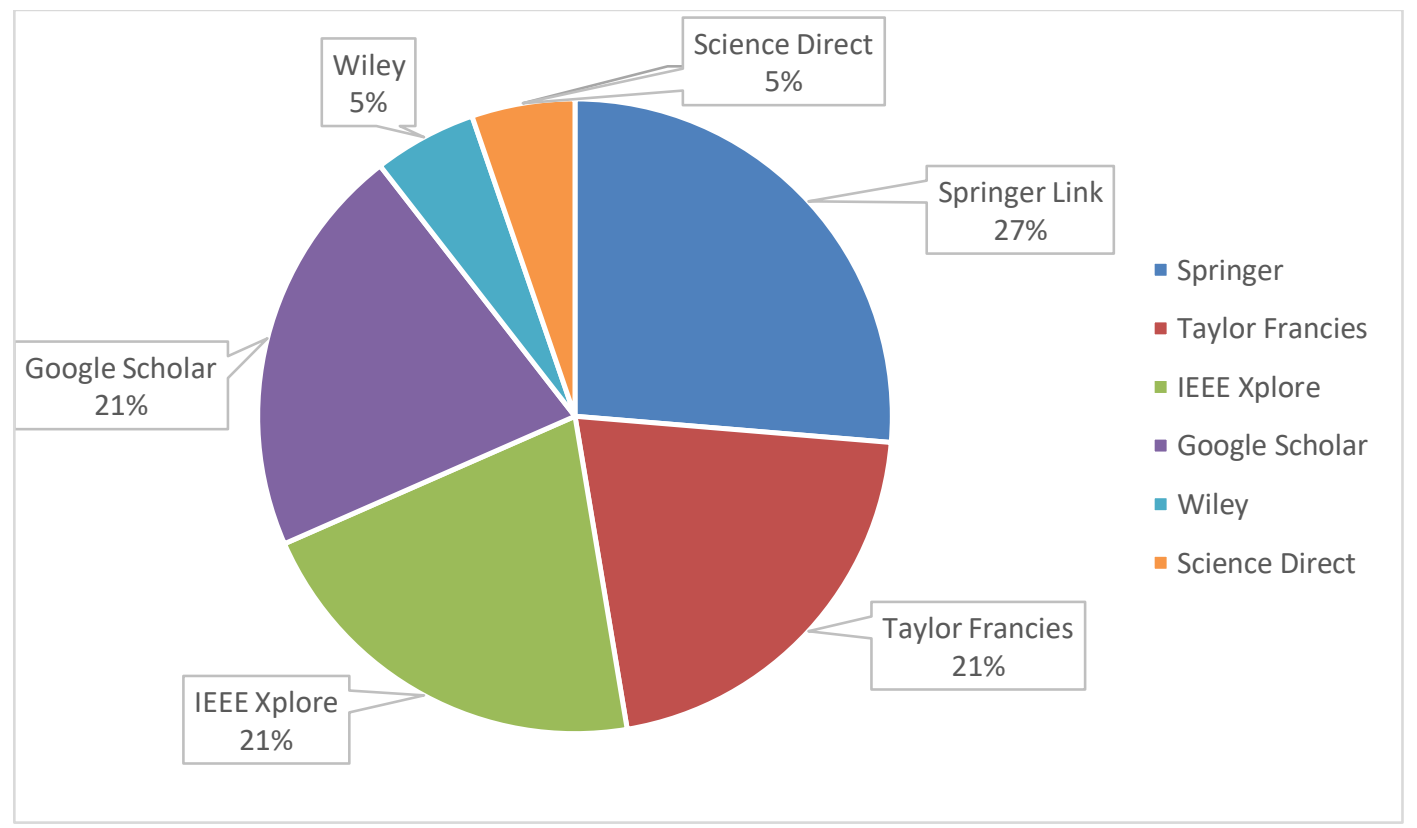

Figure 1. Online Electronic Resource 
REVISTA DE LA UNIVERSIDAD DEL ZULIA. 3época. Año $11 \mathrm{~N}^{\circ}$ 31, 2020 Sezer Kanbul et al. /// Examination on implications of Web 2.0 Tools ...559-570 DOI: http://dx.doi.org/10.46925//rdluz.31.37

When Figure 1 is examined, it can be said that the number of Web 2.0 studies in the field of special education is only a small number due to the fact that there are only 19 of the 1220 articles.

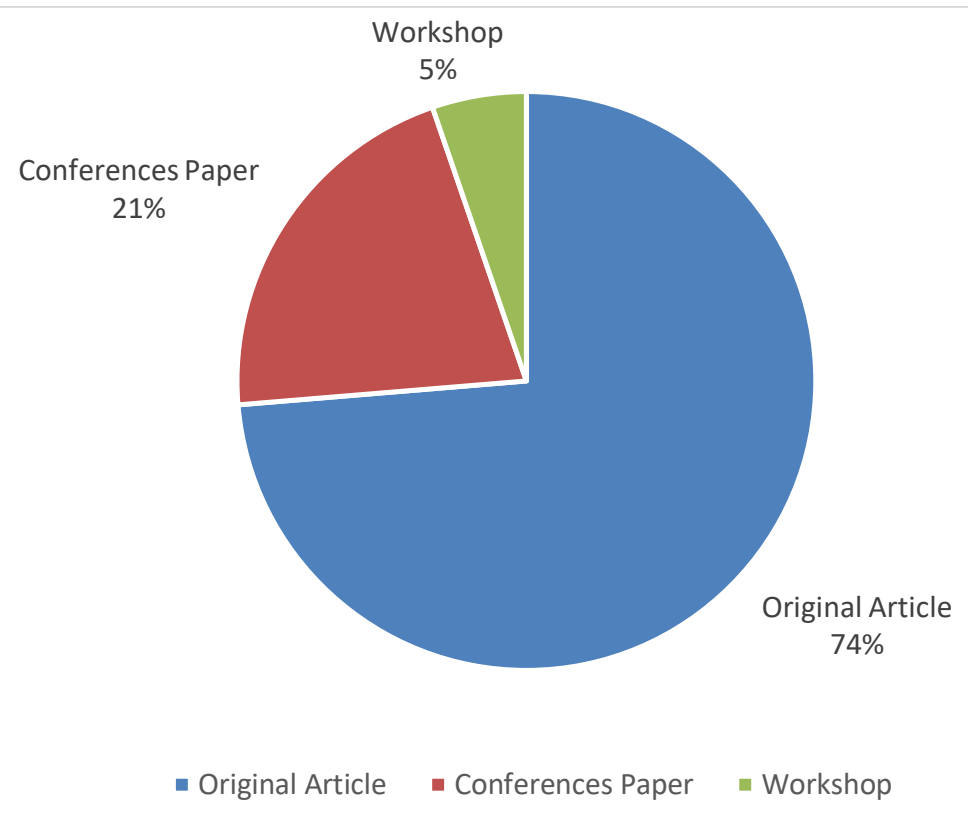

Figure 2. Article type

When Figure 2 is examined, it can be said that original articles are in the majority.

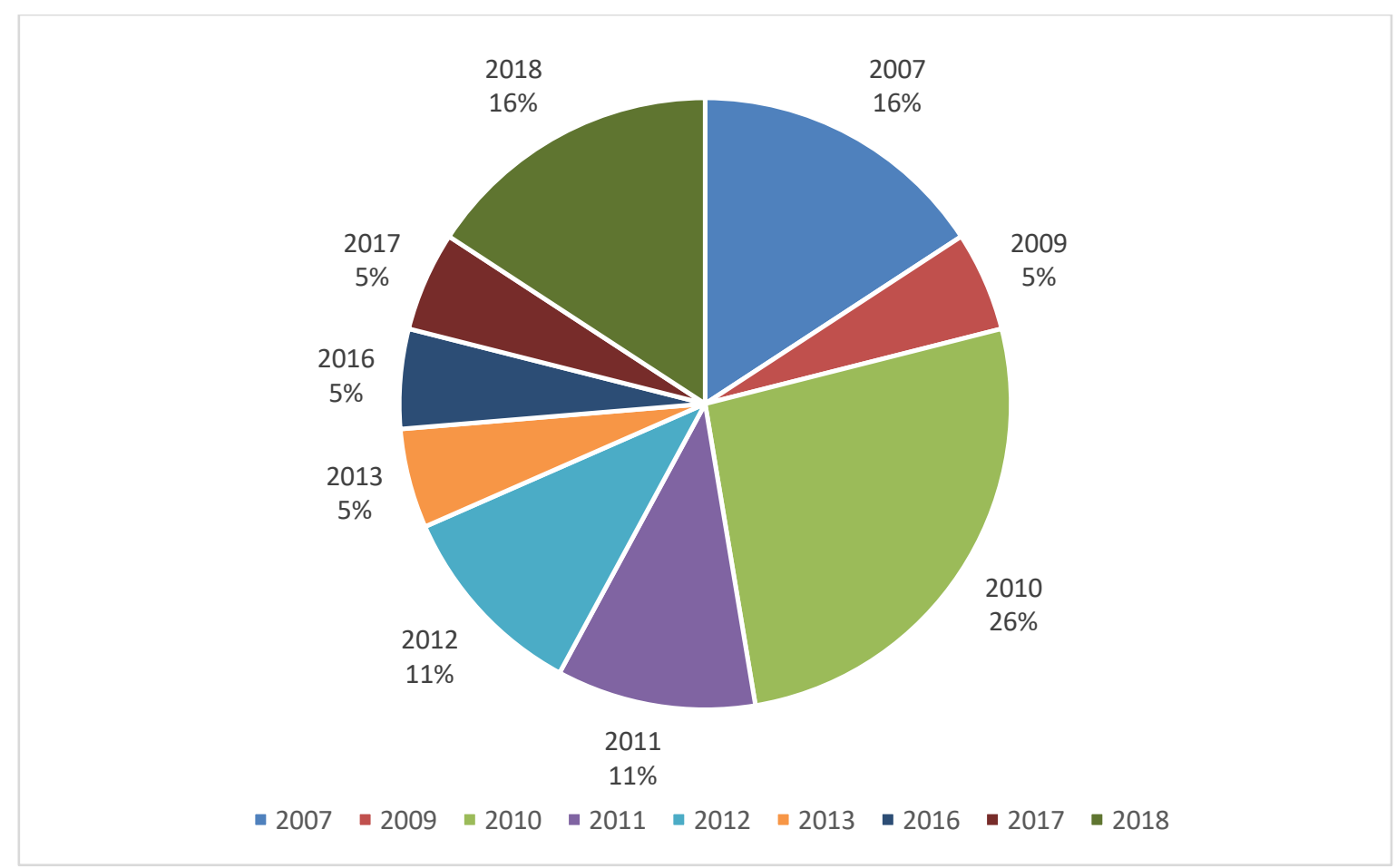

Figure 3. Publish year 
REVISTA DE LA UNIVERSIDAD DEL ZULIA. 3época. Año $11 \mathrm{~N}^{\circ}$ 31, 2020

Sezer Kanbul et al. /// Examination on implications of Web 2.0 Tools ...559-570

DOI: $\underline{\text { http://dx.doi.org/10.46925//rdluz.31.37 }}$

When Figure 3 is examined, it is seen that the studies titled Web 2.0 in the field of special education were conducted between 2007 and 2018.

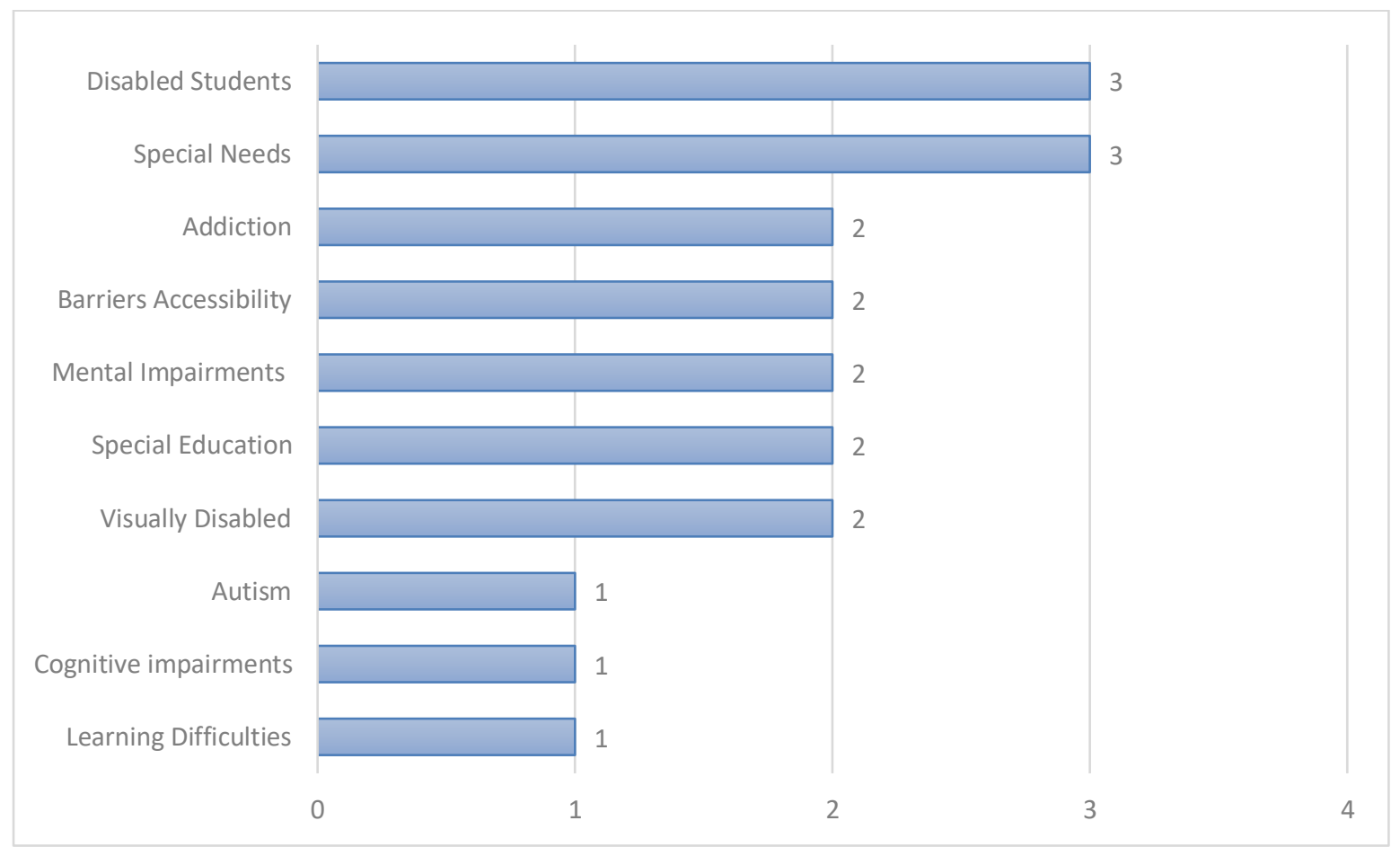

Figure 4. Article main theme

When Figure 4 is examined, it can be said that the studies are mostly focused on students with special needs and limited special education areas.

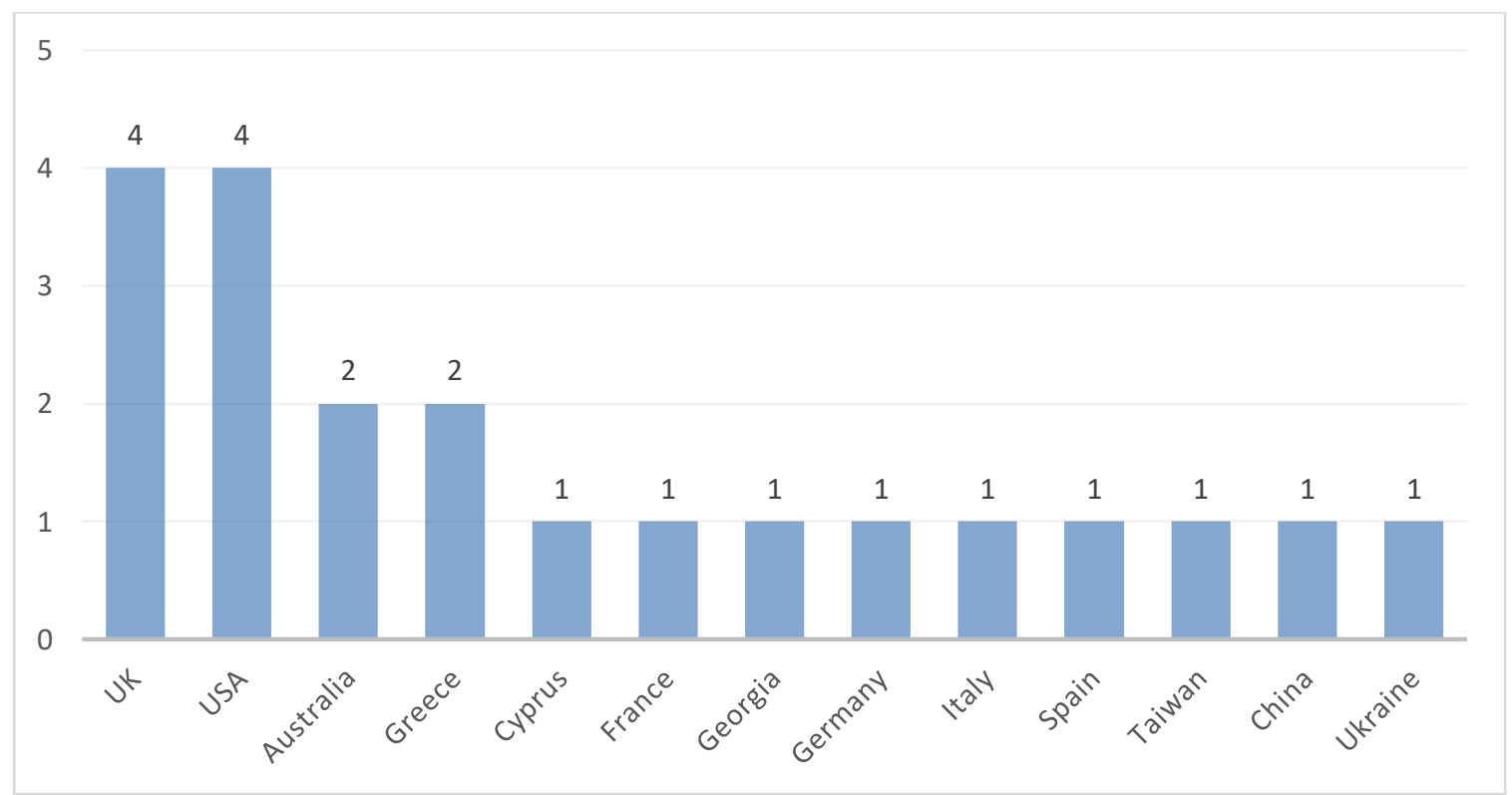

Figure 5. Author Country 
REVISTA DE LA UNIVERSIDAD DEL ZULIA. 3época. Año $11 \mathrm{~N}^{\circ}$ 31, 2020

Sezer Kanbul et al. /// Examination on implications of Web 2.0 Tools ...559-570

DOI: $\underline{\text { http://dx.doi.org/10.46925//rdluz.31.37 }}$

When the Figure 5 is examined, it is seen that the studies are mostly conducted in developed countries such as UK and USA.

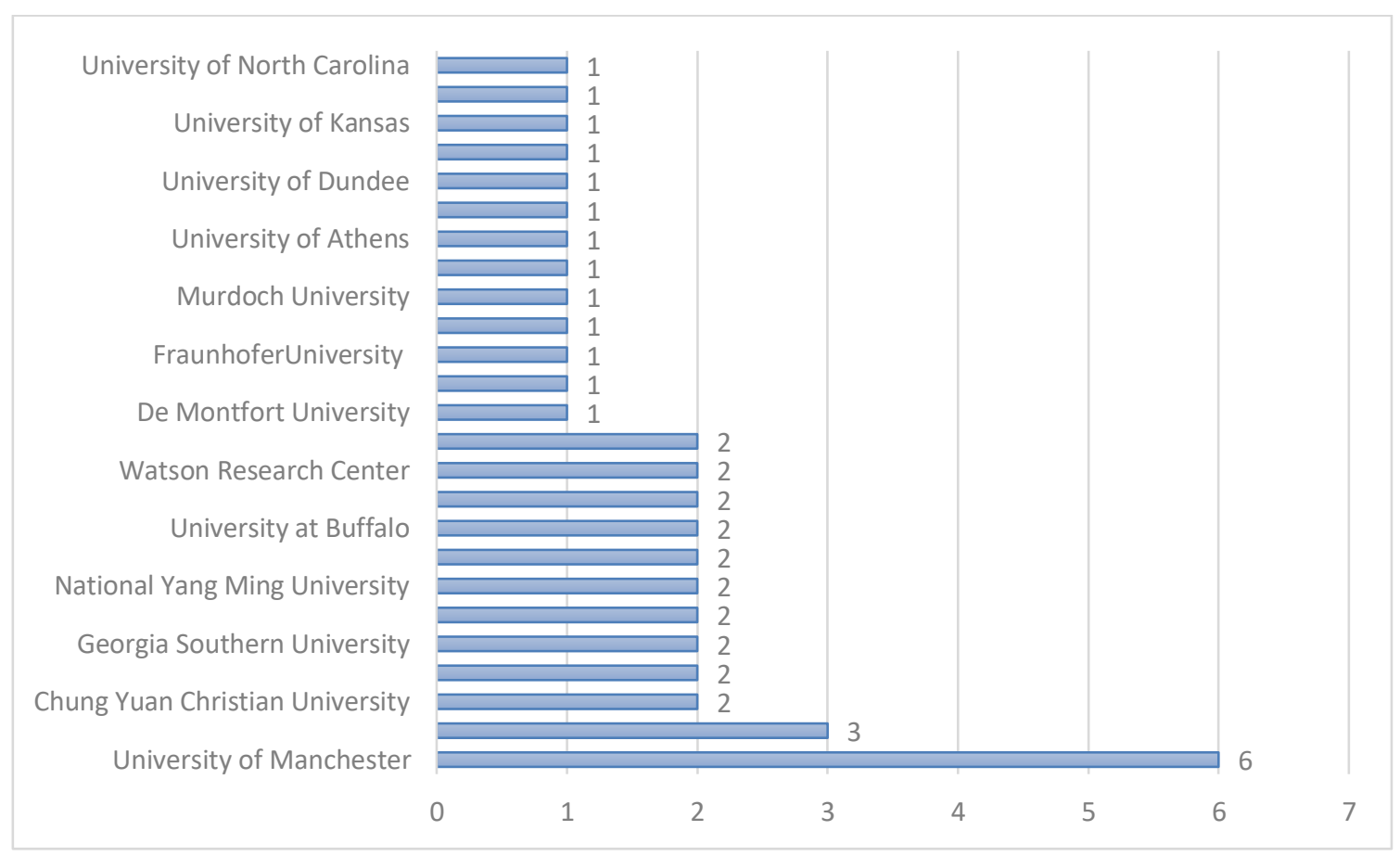

Figure 6. Author university

When Figure 6 is examined, it is seen that the studies were conducted in UK and USA universities.

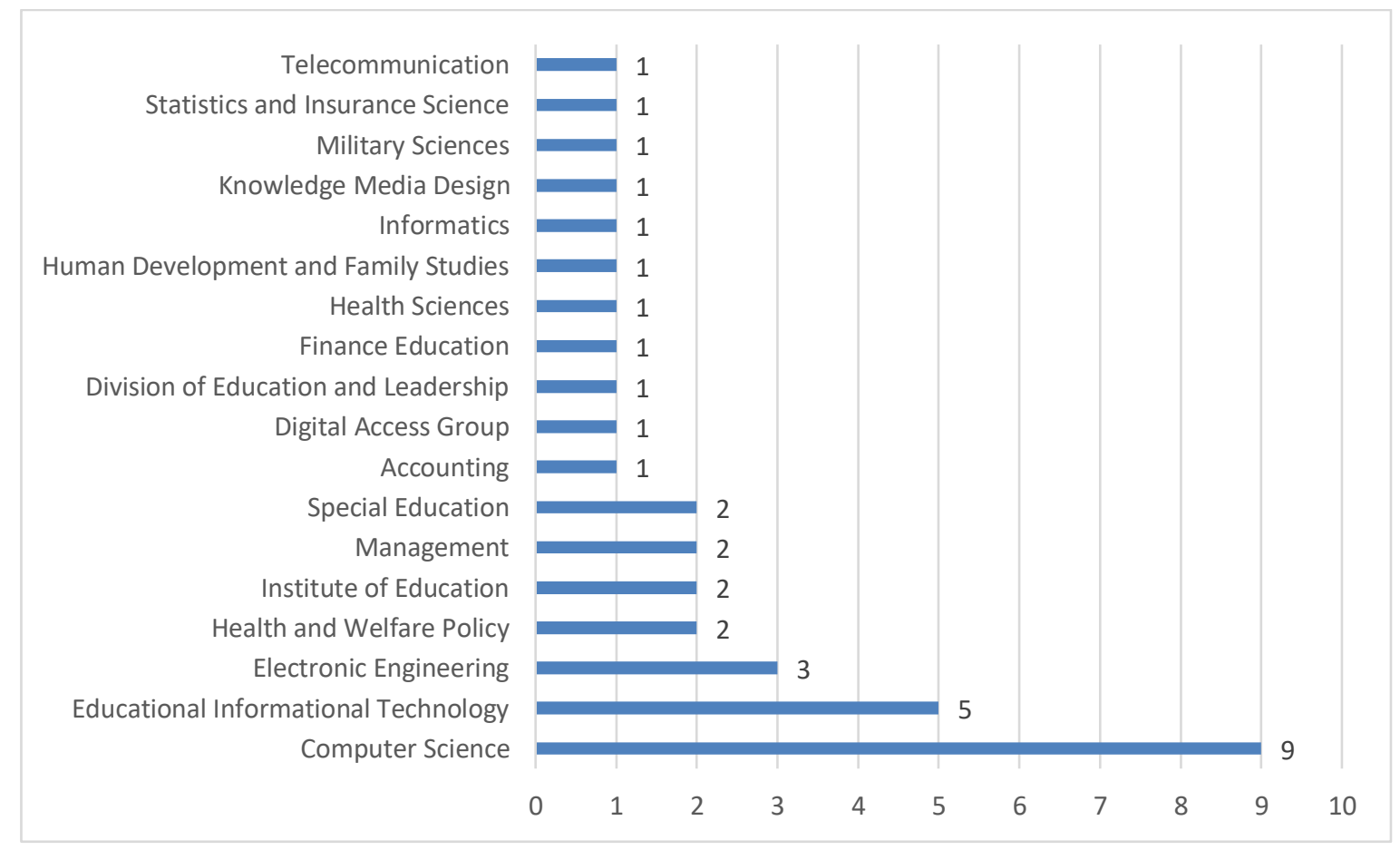

Figure 7. Author department 
REVISTA DE LA UNIVERSIDAD DEL ZULIA. 3época. Año $11 \mathrm{~N}^{\circ}$ 31, 2020 Sezer Kanbul et al. /// Examination on implications of Web 2.0 Tools ...559-570 DOI: $\underline{\text { http://dx.doi.org/10.46925//rdluz.31.37 }}$

When Figure 7 is examined, it is seen that the studies titled Web 2.0 in the field of special education are mostly studied by computer scientists and educational technologies experts.

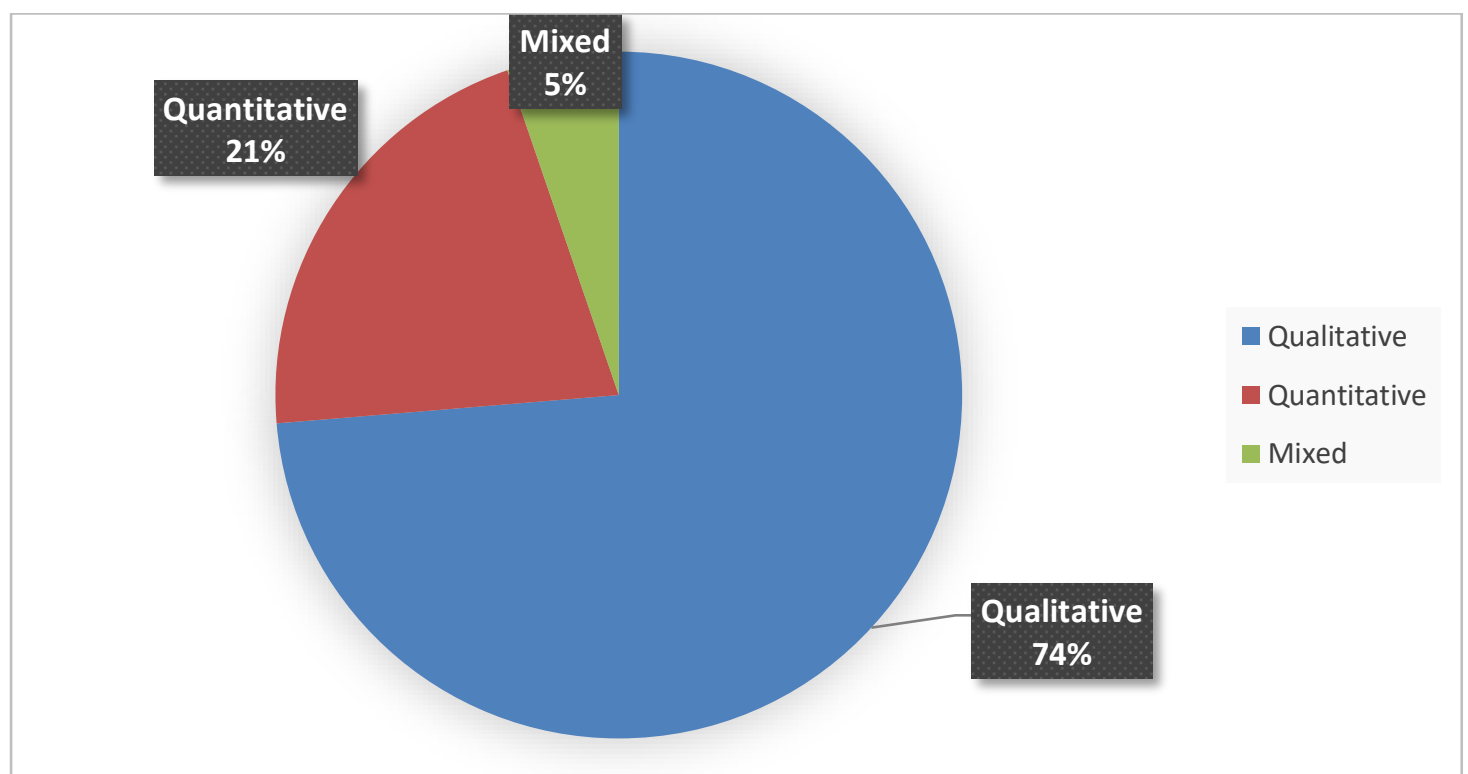

Figure 8. Research method

When Figure 8 is examined, it is seen that the studies are mostly qualitative.

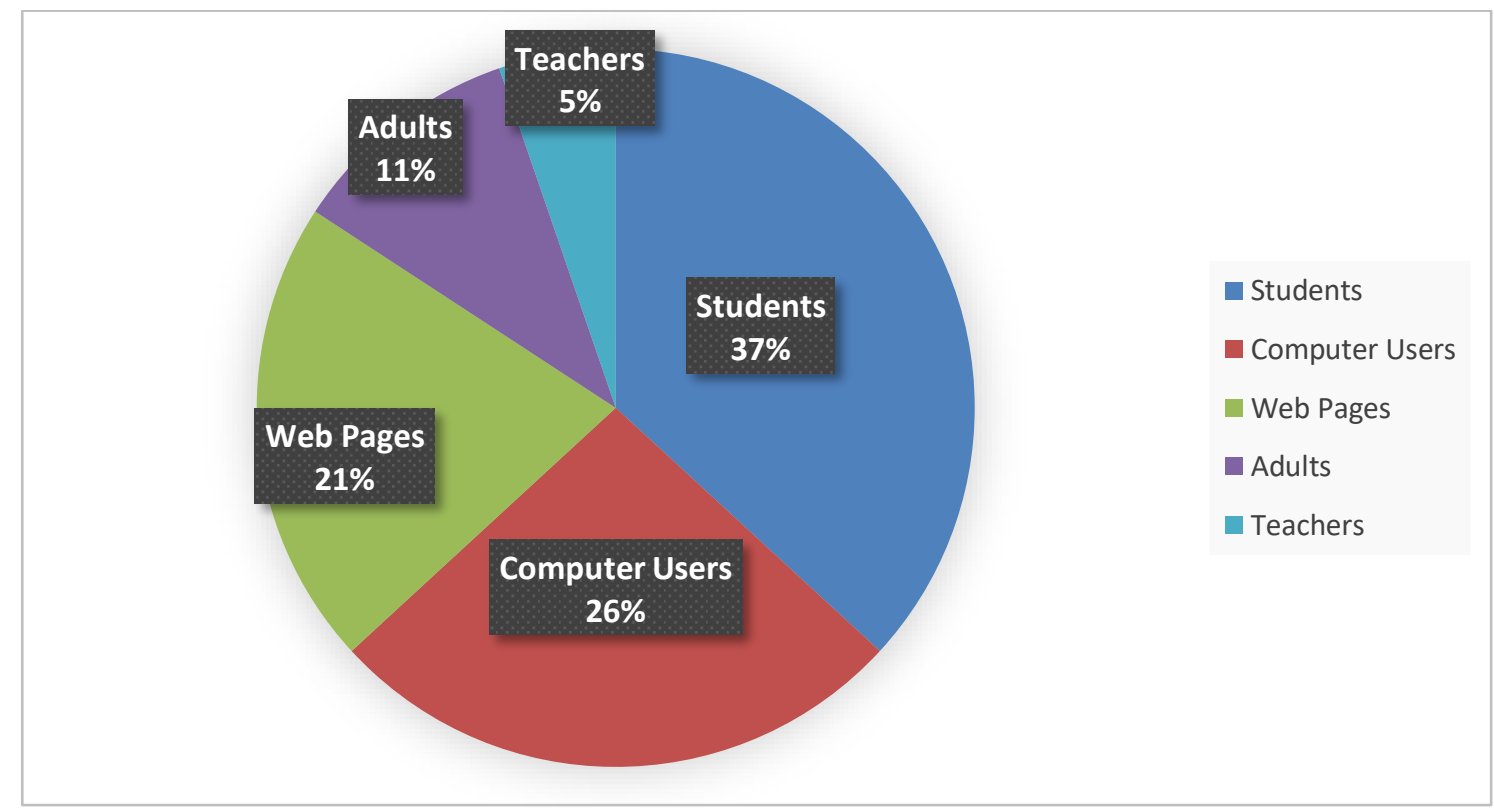

Figure 9. Sample group 
REVISTA DE LA UNIVERSIDAD DEL ZULIA. 3época. Año 11 N³ 31, 2020

Sezer Kanbul et al. /// Examination on implications of Web 2.0 Tools ...559-570

DOI: http://dx.doi.org/10.46925//rdluz.31.37

When Figure 9 is examined, it can be said that the studies were mostly conducted on students.

\section{Discussion, Conclusion and Recommendations}

In the light of the data obtained in the study, it has been attempted to reveal the tendencies of the studies conducted in the field of special education titled Web 2.0. When the results are examined:

It was concluded that the number of studies on special education in the field of Web 2.0 is low. In order for Web 2.0 tools to be used in the learning processes of students with special needs, both students and academics must have knowledge and awareness on this issue (Peterson-Ahmad et al, 2018). In a study aimed at model-based simulation and evaluation of mobile and Web 2.0 applications for students with special needs, it is integrated into the development process of accessible Web 2.0 applications by analyzing these interaction patterns and providing instrumental support for disabled people when interacting with web applications.

When the articles are examined, it is concluded that they are mostly on limited special education areas. In his study, Yeni (2017) examined the effectiveness of the in-service training program for web 2.0 tools for special education teachers with the purpose of gaining the ability to produce digital instructional materials that enabled the lessons to be presented more effectively and interactively and 18 special education teachers gained awareness.

Another noteworthy result is that Web 2.0 studies in the field of special education are mostly conducted by computer scientists and educational technologies experts.

SYNERGIA, a project of Leonardo da Vinci's Lifelong Learning Program, has been presented to provide an overview of the definition and identification of the preferences of people with hearing disabilities for particular technologies and learning strategies. The important conclusions drawn from this program are that it can be the starting point for further identification of effective methods for expanding their professional activities in numerous innovative areas, as well as promoting the digital education of physically disabled individuals. However, it is emphasized that more relevant research is needed not only from a small sample but also from a larger sample in order to provide equal access to the educational 
REVISTA DE LA UNIVERSIDAD DEL ZULIA. 3época. Año 11 N³ 31, 2020

Sezer Kanbul et al. /// Examination on implications of Web 2.0 Tools ...559-570

DOI: $\underline{\text { http://dx.doi.org/10.46925//rdluz.31.37 }}$

and professional activities of the group with hearing difficulties and hearing disabilities (Drigas et al, 2013).

Finally, it was determined that the studies were mostly conducted on the students by qualitative method. This result is up to expectations. Since students with special needs have different needs, the studies focus on small groups or single-subject studies.

Jay et al (2011) emphasizes that for people with eyesight disabilities, there will be no problem for simple text vocalization programs in order to improve access to Web 2.0, that several visual features are now inaccessible and that the case is not the same for more complex Web 2.0 pages.

In general, the specific requirements of Web 2.0 tools remain the problem of students' accessibility (Cooper, 2007; Zajicek, 2007; Pappas et al, 2010). It is believed that the results obtained will lead to further studies. In this context, some suggestions have been developed in line with the results obtained. According to this;

- $\quad$ Special education trainers and prospective teachers should be provided with in-service courses on Web 2.0 tools.

- Academicians whose field is educational technology and special education should publish scientific publications about the use of Web 2.0 technologies in special education.

- $\quad$ Educational technology experts and software developers should develop and update Web 2.0 tools that take into account the needs of students with special needs.

\section{References}

Bauer, Martin. W. (2003). Classical content analysis: A review. In M. W. Bauer \& G. Gaskell (Eds). Qualitative researching with text, image and sound London: Sage Publication, ss. 131.

Billingsley, B., Israel, M., \& Smith, S. (2011). Supporting new special education teachers: How online resources and Web 2.0 technologies can help. Teaching Exceptional Children, 43(5), 20-29.

Calık, M., \& Sozbilir, M. (2014). Parameters of Content Analysis. Education and Science, 39(174). doi:http://dx.doi.org/10.15390/EB.2014.3412 
REVISTA DE LA UNIVERSIDAD DEL ZULIA. 3época. Año 11 N³ 31, 2020

Sezer Kanbul et al. /// Examination on implications of Web 2.0 Tools ...559-570

DOI: $\underline{\text { http://dx.doi.org/10.46925//rdluz.31.37 }}$

Cooper, M. (2007). Accessibility of emerging rich web technologies: web 2.0 and the semantic web. In Proceedings of the 2007 international cross-disciplinary conference on Web accessibility (W4A) (pp. 93-98). ACM.

Drigas, A. S., Vrettaros, J., Argiri, K., \& Bardis, N. (2013). Web 2.0 learning strategies for disabled students. Journal of applied mathematics and bioinformatics, 3(4), 125.

Jay, C., Brown, A., \& Harper, S. (2011). A 'visual-centred'mapping approach for improving access to Web 2.0 for people with visual impairments. Disability and Rehabilitation: Assistive Technology, 6(2), 97-107.

Karasar, N. (2002). Bilimsel araştırma yöntemi. (1l. Baskı.) Ankara: Nobel Yayınları.

Miles, M, B., \& Huberman, A. M. (1994). Qualitative data analysis: An expanded Sourcebook. (2nd ed). Thousand Oaks, CA: Sage.

O'Reilly T. (2007). What is web 2.0: design patterns and business models for the next generation of software. Communications \& Strategies, 65(Jan), 17-37.

Pappas, L., Schwerdtfeger, R., Cooper, M. (2010). WAI-ARIA 1.0 Primer - An introduction to rich Internet application accessibility challenges and solutions, W3C Working Draft 16 September 2010. Technical report, World Wide Web Consortium, W3C.

Pereira, L. S., \& Archambault, D. (2018). Correlating Navigation Barriers on Web 2.0 with Accessibility Guidelines. In International Conference on Computers Helping People with Special Needs (pp. 13-21). Springer, Cham.

Peterson-Ahmad, M., Stepp, J., \& Somerville, K. (2018). Teaching pre-service teachers how to utilize web 2.0 platforms to support the educational needs of students with disabilities in general education classrooms. Education Sciences, 8(2), 80.

Yeni, S. (2017). Examining the effectiveness of the in-service training program on web 2.0 tools for the special education teachers. Electronic Turkish Studies, 12(23).

Yildirim, A., \& Simsek, H. (1999). Sosyal bilimlerde nitel araştırma yöntemleri. Ankara: Seçkin Yayınevi.

Zajicek, M. (2007). Web 2.0: hype or happiness?. In Proceedings of the 2007 international cross-disciplinary conference on Web accessibility (W4A) (pp. 35-39). Acm. 